\title{
FIELD STUDIES OF PHOTOSYNTHETIC AND GROWTH RESPONSES TO IRRADIANCE IN THREE FOREST UNDERSTORY SPECIES OF THE $\mathrm{C}_{4}$ GRASS GENUS MUHLENBERGIA ${ }^{1}$
}

\author{
MARIAN SMITH ${ }^{2}$ AND CRAIG E. MARTIN \\ Department of Botany, University of Kansas, Lawrence, Kansas 66045
}

\begin{abstract}
Three species of the $\mathrm{C}_{4}$ grass genus Muhlenbergia from the forest understory- $M$. frondosa, $M$. sobolifera, and $M$. schreberi-and one species from an open prairie, M. cuspidata, were transplanted to a sunny common garden and to a forest understory. After 4 mo of growth, all species in the common garden produced more biomass and greater leaf area and number than those in the understory. Muhlenbergia cuspidata died in the understory. Chlorophyll (chl) concentrations were higher, and $\mathrm{a} / \mathrm{b}$ ratios were lower, in plants from the understory. All species were grown in the laboratory under two PPFD regimes: (1) $15 \mu \mathrm{mol} \mathrm{m}^{-2} \mathrm{~s}^{-1}$ for $9 \mathrm{~h}$ plus two 10 -min periods of $500 \mu \mathrm{mol} \mathrm{m}^{-2} \mathrm{~s}^{-1}$; and (2) $15 \mu \mathrm{mol} \mathrm{m}^{-2} \mathrm{~s}^{-1}$ for $20 \mathrm{~h}$. Total integrated PPFD, not peak photon flux density, appeared to determine all aspects of the photosynthetic responses of these plants. Characteristics of photosynthetic gas exchange in situ for $M$. frondosa and $M$. sobolifera were similar to laboratory findings. Although results indicated that the three understory species adjusted their chl characteristics and survived when grown under low levels of PPFD, they grew optimally under the higher PPFD.
\end{abstract}

\section{Introduction}

Since the discovery of the $\mathrm{C}_{4}$ metabolic pathway (KORTSCHAK et al. 1965), many studies have shown that $\mathrm{C}_{4}$ plants, as a result of their higher ATP requirement, are adapted to sunny environments (BJÖRKMAN and BERRY 1973; HATCH and OSMOND 1976). The distribution of $C_{4}$ species generally supports this conclusion, with most $\mathrm{C}_{4}$ plants restricted to warm, sunny habitats (TEERI and STOWE 1976; DOLINER and JOLLIFFE 1979; TIESZEN et al. 1979; TeERI et al. 1980). However, the discovery of several $\mathrm{C}_{4}$ species growing in forest understories (BROWN 1977; Winter et al. 1982; PEARCY 1983; PEARCY and CALKIN 1983; WARD and WoOlHOUSE 1986) challenged the dogma that the distribution of these plants is determined primarily by their photosynthetic pathway (PEARCY and EHLERINGER 1984).

Three species of the $\mathrm{C}_{4}$ grass genus Muhlenbergia $-M$. frondosa, $M$. sobolifera, and $M$. schreberi-occur in the understory of deciduous forests in eastern Kansas (Great Plains Flora AssociATION 1986). Although the understory PPFD levels are often as low as $15 \mu \mathrm{mol} \mathrm{m} \mathrm{m}^{-2} \mathrm{~s}^{-1}$, transient sun flecks that vary from 100 to $1,700 \mu \mathrm{mol} \mathrm{m}^{-2} \mathrm{~s}^{-1}$ periodically illuminate the plants through breaks in the canopy throughout the day. These sun flecks

\footnotetext{
${ }^{1}$ Abbreviations: A, assimilation; ANCOVA, analysis of covariance; ANOVA, analysis of variance; chl, chlorophyll; $c_{\mathrm{i}}$, intercellular $\mathrm{CO}_{2}$ concentration; $g_{\mathrm{c}}$, conductance to $\mathrm{CO}_{2} ; \mathrm{LA}$, leaf area; LDW, leaf dry weight; $\mathrm{LN}$, leaf number; LSD, least significant difference; PPFD, photosynthetic photon flux density; RDW, root dry weight; SDW, stem dry weight; TDW, total dry weight.

${ }^{2}$ Current address and address for correspondence and reprints: Department of Biological Sciences, Southern Illinois University, Edwardsville, Illinois 62026.

Manuscript received August 1986; revised manuscript received March 1987.
}

can vary in duration from $30 \mathrm{~s}$ to $20 \mathrm{~min}$ (personal observation).

In laboratory studies (SMITH and MARTIN 1987a, $1987 b$ ), the three understory species, when compared with $M$. cuspidata, which is restricted to open prairie, exhibited characteristics of shade tolerance: (1) substantial biomass production at low PPFD; (2) an increase in chl content and a decrease in chl a/b ratios with decreasing PPFD; (3) photosynthetic $\mathrm{CO}_{2}$ exchange and photosystem I electron transport saturation at low levels of PPFD; and (4) high quantum yields in plants grown at low PPFD. The four species of Muhlenbergia produced more biomass under higher PPFD than existed in their natural habitats (SMITH and MARTIN 1987a).

For a better understanding of this paradoxical finding, field studies were conducted in which growth and chl responses of plants grown in a forest understory were compared with those of plants grown in a sunny common garden, and photosynthetic gas exchange was measured in situ for $M$. frondosa and $M$. sobolifera. In addition, to assess the potential ability of these species to capitalize on transient sun flecks, a laboratory study was conducted to determine their chl and photosynthetic responses to brief periods of high PPFD.

\section{Material and methods}

\section{TRANSPLANT EXPERIMENT}

Muhlenbergia frondosa (Poir.) Fern. and M. sobolifera (Muhl.) Trin. were collected from the understory of an oak-hickory forest (WELLS and MORLEY 1964) $14 \mathrm{~km} \mathrm{~S}$ of Lawrence, Kansas (Douglas Co.). Rhizomes of $M$. frondosa were collected along a 200-m transect of an abandoned railway bed. Levels of PPFD varied from less than $150 \mu \mathrm{mol} \mathrm{m}{ }^{-2} \mathrm{~s}^{-1}$ under the canopy to full sunlight in open areas. Rhizomes of $M$. sobolifera were col- 
lected from a site ca. $100 \mathrm{~m}$ from the railway bed on a steep, moist bank above a stream. The PPFD levels at the site were ca. $10-25 \mu \mathrm{mol} \mathrm{m}{ }^{-2} \mathrm{~s}^{-1}$ except during transitory sun flecks.

Muhlenbergia schreberi Gmel. was collected beneath a canopy of Juniperus virginiana along a small creek near an unpaved road $0.5 \mathrm{~km} \mathrm{NW}$ of Alma, Kansas (Wabaunsee Co.). The PPFD levels below the canopy were $300-1,500 \mu \mathrm{mol} \mathrm{m}{ }^{-2} \mathrm{~s}^{-1}$. Muhlenbergia cuspidata (Torre.) Rydb. was collected from an open prairie $1.6 \mathrm{~km}$ E of Hiattville, Kansas (Linn Co.), in dense clumps in cracks and at the edges of limestone outcrops.

Plants were transplanted to an open, sunny common garden in the Nelson Environmental Study Area of the University of Kansas, $18 \mathrm{~km}$ NE of Lawrence in Jefferson County, $0.5 \mathrm{~km}$ E of County Road 9. The upper $10 \mathrm{~cm}$ of soil were tilled in four $1 \times$ $1-\mathrm{m}$ plots, and 30 plants of each species were placed ca. $15 \mathrm{~cm}$ apart in rows and covered with $10 \mathrm{~cm}$ of soil. Stems were clipped at ground level. The immediate area was cleared of other vegetation, and the plots were weeded regularly, but not watered, during the study. Levels of PPFD at the site, determined at 1500 hours (no. $=3$ ) on a clear day, ranged from 1,700 to $2,000 \mu \mathrm{mol} \mathrm{m} \mathrm{m}^{-2} \mathrm{~s}^{-1}$.

A second group of plants was transplanted in an identical fashion to a forest understory ca. $2 \mathrm{~km}$ from the common garden site. The canopy was composed of Ulmus rubra, Carya ovata, and Celtis occidentalis and saplings of Cercis canadensis and Toxicodendron radicans. Levels of PPFD on the day of planting, when the trees had not fully leafed out, varied from ca. 700 to $1,000 \mu \mathrm{mol} \mathrm{m}^{-2}$ $\mathrm{s}^{-1}$. Two weeks later, PPFD (no. $=5$ ) varied from 25 to $300 \mu \mathrm{mol} \mathrm{m}{ }^{-2} \mathrm{~s}^{-1}$ under the full canopy.

Plants from both transplant areas were harvested after 4 mo of growth. The LA was determined with a LI-COR (Lincoln, Neb.) LI-3000 leaf area meter for five samples randomly chosen from each species and each treatment. The chl content and chl $\mathrm{a} / \mathrm{b}$ ratios were determined (SMITH and MARTIN $1987 b$ ). All chl data were statistically analyzed by ANOVA, and means were compared for LSD (SoKAL and ROHLF 1981). Statistical difference was inferred when $P<.05$.

The remaining plants were oven-dried at $80 \mathrm{C}$ for 4 days for biomass determinations. All biomass data were analyzed by ANCOVA. Rhizome dry weight, closely correlated with initial rhizome fresh weight (determined previously), was the covariate in all biomass analyses. Means were compared for LSD.

\section{LIGHT FLECK EXPERIMENT}

Rhizomes of all species were collected, potted, and grown for 28-35 days in the laboratory (SMITH and MARTIN 1987a). Twenty plants of each species were placed under two PPFD regimes: (1) $15 \mu \mathrm{mol}$ $\mathrm{m}^{-2} \mathrm{~s}^{-1}$ for $20 \mathrm{~h}$, and (2) $15 \mu \mathrm{mol} \mathrm{m}^{-2} \mathrm{~s}^{-1}$ for 9 $\mathrm{h}$ plus two 10 -min periods of $500 \mu \mathrm{mol} \mathrm{m} \mathrm{m}^{-2} \mathrm{~s}^{-1}$ (integrated daily irradiance $=1.08 \mathrm{~mol} \mathrm{~m}^{-2}$ for both sets of plants).

Photosynthetic gas exchange from each PPFD regime was measured on three attached leaves of each species. The gas exchange system was as described by SMITH and MARTIN (1987b) except that (1) air temperature varied from 27 to $31 \mathrm{C}$; (2) vapor pressure deficit varied from 1.75 to $2.70 \mathrm{kPa}$; and (3) mean $\mathrm{CO}_{2}$ concentration was $346 \mu \mathrm{L} \mathrm{L}^{-1}$ $(\mathrm{SD}=8$, no. $=54)$.

After gas exchange measurements, LA and chl concentrations were determined. $\mathrm{CO}_{2}$ and $\mathrm{H}_{2} \mathrm{O}$ exchange rates were measured (SĚSTÁK et al. 1971), and $\mathrm{A}, g_{\mathrm{c}}$, and $c_{\mathrm{i}}$ were calculated (FARQUHAR and VON CAEMMERER 1982).

All gas exchange data were analyzed by a twoway ANOVA (SPSS ${ }^{\mathrm{x}}$, Chicago, Ill.), and means were compared for LSD (SOKAL and ROHLF 1981). Statistical difference was inferred when $P<.05$.

\section{FIELD PHOTOSYNTHESIS}

On 2 clear days in August 1984, photosynthetic measurements were determined in situ on 18-20 plants of $M$. frondosa and $M$. sobolifera. Measurements were made on a single attached leaf of each plant and included plants both in and out of transient sun flecks. Leaf temperatures were 17$31 \mathrm{C}$; chamber relative humidity, $7 \%-35 \%$; and light levels, 5-1,700 $\mu \mathrm{mol} \mathrm{m}^{-2} \mathrm{~s}^{-1}$ PPFD. All data were calculated with a LI-COR LI-6000 portable photosynthesis system $(0.25 \mathrm{~L}$ chamber $)$ calibrated every $2 \mathrm{~h}$.

\section{Results and discussion}

\section{TRANSPLANT EXPERIMENT}

The failure of Muhlenbergia cuspidata, a prairie plant, to survive in the understory is consistent with results obtained for plants grown in the laboratory at low PPFD (SMITH and MARTIN 1987a) and further emphasizes that this species is an obligate sun plant.

Although $M$. frondosa, $M$. sobolifera, and $M$. schreberi survived when transplanted to the understory, exhibiting some degree of shade tolerance, all three species produced significantly greater biomass (TDW, SDW, LDW, and RDW) when grown in a common garden (table 1). In addition, $\mathrm{LA}$ and LN were greater for these three species grown in the common garden (table 2). Although growth conditions are not identical with those in the laboratory growth experiments (SMITH and MARTIN 1987a), the field data corroborate results obtained under laboratory high and low PPFD regimes. Both experiments indicate that, although the species survive at reduced PPFD, they are able to exploit higher levels of light when available during 


\section{TABLE 1}

EFFECTS OF PPFD LEVEL ON PLANT, STEM, LEAF, AND ROOT (INCLUDING RHIZOME) BIOMASS (TDW, SDW, LDW, RDW) (g) IN THREE UNDERSTORY AND ONE PRAIRIE SPECIES OF MUHLENBERGIA

\begin{tabular}{|c|c|c|}
\hline \multirow[b]{2}{*}{ SPECIES } & \multicolumn{2}{|c|}{ GROWTH ENVIRONMENT } \\
\hline & $\begin{array}{c}\text { Common garden } \\
\bar{X} \pm \mathrm{SE}\end{array}$ & $\begin{array}{c}\text { Understory } \\
\bar{X} \pm \mathrm{SE}\end{array}$ \\
\hline M. frondosa: & $($ No. $=28)$ & $($ No. $=22)$ \\
\hline TDW $\ldots .$. & $3.82 \pm .37 a$ & $.30 \pm .03 b$ \\
\hline SDW. & $1.30 \pm .09 a$ & $.09 \pm .01 b$ \\
\hline LDW. & $.70 \pm .07 a$ & $.06 \pm .01 b$ \\
\hline RDW ........ & $1.83 \pm .20$ & $.16 \pm .02$ \\
\hline M. sobolifera: & $($ No. $=23)$ & $($ No. $=27)$ \\
\hline TDW ....... & $1.76 \pm .24 \mathrm{a}$ & $.40 \pm .05 b$ \\
\hline SDW. & $.54 \pm .08 \mathrm{a}$ & $.09 \pm .01 b$ \\
\hline LDW .. & $.41 \pm .06 a$ & $.09 \pm .01 \mathrm{~b}$ \\
\hline RDW ......... & $.71 \pm .11$ & $.23 \pm .03$ \\
\hline M. schreberi: & $($ No. $=23)$ & $($ No. $=16)$ \\
\hline TDW ..... & $1.65 \pm .21 \mathrm{a}$ & $.07 \pm .01 b$ \\
\hline SDW. & $.87 \pm .11 \mathrm{a}$ & $.02 \pm<.01 \mathrm{~b}$ \\
\hline LDW. & $.33 \pm .04 a$ & $.01 \pm .01 \mathrm{~b}$ \\
\hline RDW ... & $.46 \pm .06$ & $.04 \pm .01$ \\
\hline M. cuspidata: & $($ No. $=23)$ & \\
\hline TDW $\ldots . .$. & $.45 \pm .05$ & a \\
\hline SDW $\ldots \ldots$ & $.19 \pm .02$ & a \\
\hline LDW ....... & $.10 \pm .01$ & a \\
\hline RDW $\ldots \ldots \ldots \ldots$ & $.12 \pm .02$ & a \\
\hline
\end{tabular}

NOTE.-Probabilities were calculated from ANCOVA. Only means with different letters differ significantly $(P<.05$, LSD). ${ }^{\mathrm{a}}$ No plants survived.

TABLE 2

EFFECTS OF PPFD ON LA $\left(\mathrm{cm}^{2}\right)$ AND LN IN THREE UNDERSTORY AND ONE PRAIRIE SPECIES OF MUHLENBERGIA

\begin{tabular}{|c|c|c|}
\hline \multirow[b]{2}{*}{ SPECIES } & \multicolumn{2}{|c|}{ GROWTH ENVIRONMENT } \\
\hline & $\begin{array}{c}\text { Common garden } \\
\bar{X} \pm \mathrm{SE}\end{array}$ & $\begin{array}{c}\text { Understory } \\
\bar{X} \pm \mathrm{SE}\end{array}$ \\
\hline \multicolumn{3}{|l|}{ M. frondosa: } \\
\hline LA $(5,10)^{\mathrm{a}}$ & $.221 .67 \pm 42.72 \mathrm{a}$ & $21.85 \pm 2.12 b$ \\
\hline $\operatorname{LN}(28,22)^{\mathrm{a}}$ & $99.79 \pm 8.61 \mathrm{a}$ & $13.45 \pm 1.17 \mathrm{~b}$ \\
\hline \multicolumn{3}{|l|}{ M. sobolifera: } \\
\hline LA $(4,11)$ & $.128 .28 \pm 55.00^{\mathrm{b}}$ & $27.54 \pm 4.36$ \\
\hline LN $(23,27)$ & $79.09 \pm 12.81^{\mathrm{b}}$ & $12.44 \pm 1.07$ \\
\hline \multicolumn{3}{|l|}{ M. schreberi: } \\
\hline LA $(5,6)$ & $75.13 \pm 14.27^{\mathrm{b}}$ & $2.60 \pm 25$ \\
\hline LN $(23,16)$ & $.109 .61 \pm 14.62 \mathrm{a}$ & $7.31 \pm .65 b$ \\
\hline \multicolumn{3}{|l|}{ M. cuspidata: } \\
\hline LA (5) $\ldots$ & $16.90 \pm 6.91$ & $\mathrm{c}$ \\
\hline LN (23) ... & $24.74 \pm 2.35$ & $\mathrm{c}$ \\
\hline
\end{tabular}

NOTE.-Probabilities were calculated from ANCOVA. Only means with different letters differ significantly $(P<.05$, LSD).

${ }^{a}$ Nos. in parentheses are sample sizes for common garden and understory, respectively.

${ }^{b}$ The slopes of the regression lines for the different light levels were not parallel; therefore, no further testing of the means was attempted.

${ }^{\mathrm{c}}$ No plants survived. growth. Similar results were observed in Microstegium vimineum (WINTER et al. 1982) and Paspalum conjugatum (WARD and WOOLHOUSE 1986), other shade-adapted $\mathrm{C}_{4}$ plants. The greatest degree of shade tolerance in the present transplant study is observed in M. sobolifera, which is the only species to produce larger leaves in the understory. Also, these plants suffer less reduction in TDW (ca. 78\%) than $M$. frondosa (ca. 92\%) or M. schreberi (ca. 96\%).

Chl concentrations were lower, and chl a/b ratios higher, in plants of $M$. frondosa, $M$. sobolifera and $M$. schreberi grown in the garden than in those grown in the understory (table 3). All three species apparently adjusted chl concentrations and ratios in response to lower levels of PPFD during growth under natural conditions. Greater chl concentrations in the understory plants should result in an increase in light-harvesting ability and constitutes a physiological adjustment to shade (BJÖRKMAN 1981). This is also consistent with results obtained under laboratory conditions for these three species (SMITH and MARTIN 1987b) and with field studies of other species (GRANT and RYUGO 1984; MASAROVIČOVÁ and MINARČIC 1985). Lower $\mathrm{chl} \mathrm{a/b}$ ratios, observed in plants transplanted to the understory, are an indication of an increase in size of the light-harvesting complex, a response demonstrated by other shade-adjusted plants in field and laboratory experiments (BJÖRKMAN et al. 1972; BOARDMAN 1977; WINTER et al. 1982) and again are consistent with results obtained in our laboratory (SMITH and MARTIN 1987b).

TABLE 3

EFFECT OF PPFD ON chl CONCENTRATION ( $\mathrm{mg} \mathrm{g}^{-1} \mathrm{DW}$ ) AND chl $a / b$ RATIOS IN THREE UNDERSTORY SPECIES AND ONE PRAIRIE SPECIES OF MUHLENBERGIA

\begin{tabular}{|c|c|c|}
\hline \multirow[b]{2}{*}{ SPECIES } & \multicolumn{2}{|c|}{ GROWTH ENVIRONMENT } \\
\hline & $\begin{array}{c}\text { Common garden } \\
\bar{X} \pm \mathrm{SE}\end{array}$ & $\begin{array}{l}\text { Understory } \\
\bar{X} \pm \text { SE }\end{array}$ \\
\hline M. frondosa: & $($ No. $=10)$ & $($ No. $=10)$ \\
\hline Chl concentration. & $4.42 \pm .38 a$ & $12.02 \pm 1.00 \mathrm{~b}$ \\
\hline Chl $\mathrm{a} / \mathrm{b}$ ratio $\ldots$. & $3.37 \pm .13 a$ & $2.54 \pm .03 b$ \\
\hline M. sobolifera: & $($ No. $=10)$ & $($ No. $=7)$ \\
\hline Chl concentration. ... & $2.20 \pm .22 \mathrm{a}$ & $11.28 \pm .73 b$ \\
\hline $\mathrm{Chl} \mathrm{a} / \mathrm{b}$ ratio $\ldots \ldots$ & $2.95 \pm .06 a$ & $2.63 \pm .09 \mathrm{~b}$ \\
\hline M. schreberi: & $($ No. $=10)$ & $($ No. $=6)$ \\
\hline Chl concentration.... & $4.97 \pm .35 a$ & $15.37 \pm .99 b$ \\
\hline Chl $\mathrm{a} / \mathrm{b}$ ratio $\ldots \ldots$ & $3.30 \pm .08 a$ & $2.54 \pm .04 \mathrm{~b}$ \\
\hline M. cuspidata: & $($ No. $=10)$ & \\
\hline Chl concentration. . & $3.80 \pm .13$ & a \\
\hline $\mathrm{Chl}$ a/b ratio ..... & $3.60 \pm .03$ & a \\
\hline
\end{tabular}

NOTE.-Only means with different letters differ significantly $(P<.05$, LSD $)$.

${ }^{\text {a }}$ No plants survived. 
TABLE 4

EFFECT OF DIFFERENT PEAK PHOTON FLUX DENSITIES (SAME DAILY TOTAL) ON chl CONCENTRATION ( $\mathrm{mg} \mathrm{g}^{-1}$ DW) AND chl a/b RATIOS IN THREE UNDERSTORY SPECIES AND ONE PRAIRIE SPECIES OF MUHLENBERGIA

\begin{tabular}{|c|c|c|}
\hline \multirow[b]{2}{*}{ SPECIES } & \multicolumn{2}{|c|}{ GROWTH LIGHT REGIME } \\
\hline & $\begin{array}{c}\text { Light fleck } \\
\bar{X} \pm \text { SE }\end{array}$ & $\begin{array}{c}\text { Low light } \\
\bar{X} \pm \mathrm{SE}\end{array}$ \\
\hline \multicolumn{3}{|l|}{ M. frondosa: } \\
\hline Chl concentration. & $21.28 \pm 1.89$ & $24.62 \pm 2.89$ \\
\hline Chl a/b ratio $\ldots$. & $2.71 \pm .08$ & $2.76 \pm .09$ \\
\hline \multicolumn{3}{|l|}{ M. sobolifera: } \\
\hline Chl concentration & $28.79 \pm 2.13$ & $20.54 \pm 7.52$ \\
\hline $\mathrm{Chl} \mathrm{a} / \mathrm{b}$ ratio $\ldots$ & $2.43 \pm .14$ & $2.39 \pm .20$ \\
\hline \multicolumn{3}{|l|}{ M. schreberi: } \\
\hline Chl concentration & $6.41 \pm .72 a$ & $16.86 \pm$ \\
\hline Chl a/b ratio .... & $2.99 \pm .09$ & $2.97 \pm .10$ \\
\hline
\end{tabular}

NOTE.-Light fleck $=15 \mu \mathrm{mol} \mathrm{m} \mathrm{m}^{-2} \mathrm{~s}^{-1}$ for $9 \mathrm{~h}$ and 500 $\mu \mathrm{mol} \mathrm{m} \mathrm{m}^{-2} \mathrm{~s}^{-1}$ for two 10 -min periods. Low light $=15 \mu \mathrm{mol}$ $\mathrm{m}^{-2} \mathrm{~s}^{-1}$ for $20 \mathrm{~h}_{\text {day }}{ }^{-1}$. Only means with different letters differ significantly $(P<.05, \mathrm{LSD})$. No. $=3$ for all species. Muh lenbergia cuspidata did not survive under either regime.

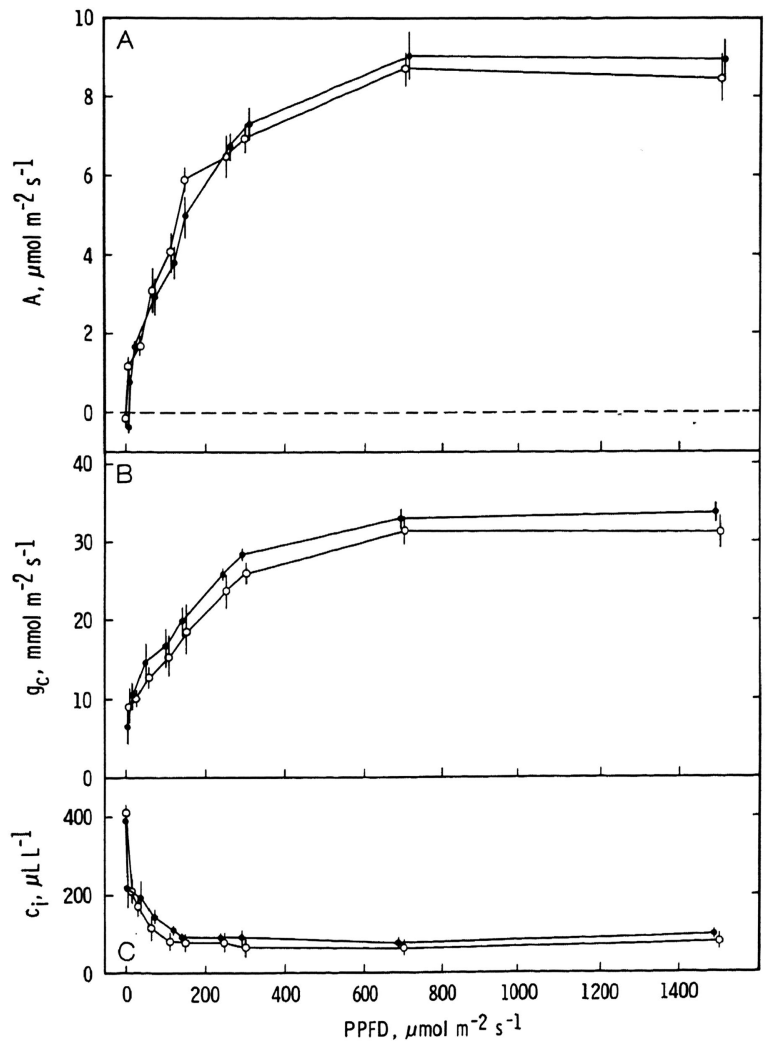

FIG. 1.-Muhlenbergia frondosa. A, Assimilation rate (A); $B$, leaf conductance $\left(g_{\mathrm{c}}\right)$; and $C$, intercellular $\mathrm{CO}_{2}$ concentration $\left(c_{\mathrm{i}}\right)$ as functions of light. Plants were grown for 28-35 days at the following light levels (same daily fluence rate): $O$, light fleck $=15 \mu \mathrm{mol} \mathrm{m}^{-2} \mathrm{~s}^{-1}$ for $9 \mathrm{~h}$ plus two 10 -min periods of $500 \mu \mathrm{mol} \mathrm{m} \mathrm{m}^{-2} \mathrm{~s}^{-1}$. , low light $=15 \mu \mathrm{mol} \mathrm{m} \mathrm{m}^{-2} \mathrm{~s}^{-1}$ for 20 h. Data are means and SE of three plants.

\section{LIGHT FLECK EXPERIMENT}

Plants of $M$. cuspidata failed to survive under both PPFD regimes. Brief increases in PPFD had no effect on chl (table 4) or photosynthetic responses (figs. 1-3) in M. frondosa, M. sobolifera, and $M$. schreberi relative to plants grown at constant low PPFD. One exception was the chl content of $M$. schreberi, which decreased under the light regime with two periods of high PPFD.

The similarity in photosynthetic responses to PPFD of plants of $M$. frondosa, $M$. sobolifer $a$, and $M$. schreberi from both PPFD regimes to increasing instantaneous PPFD indicates that the integrated amount of PPFD received during growth was the limiting factor, not the peak photon flux density. Similar results, in terms of growth as well as photosynthesis, were demonstrated by HURD and THORNLEY (1974), NoBEL (1976), and CHABOT et al. (1979). Shade-adapted species of the $\mathrm{C}_{4}$ genus Euphorbia in Hawaiian forests, however, respond to sun flecks uniquely and maintain higher $\mathrm{CO}_{2}$ assimilation rates than expected, given the integrated daily PPFD (PeARCY and CALKIN 1983; PeARCY et al. 1985).

For the three understory species in the present study, A curves were nearly identical with those

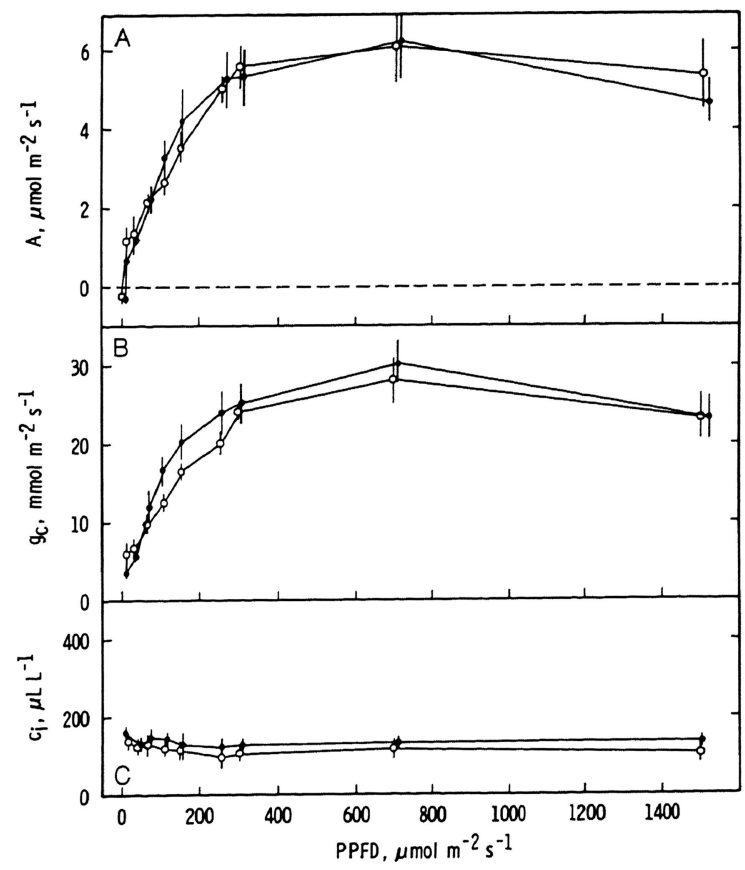

FIG. 2.-Muhlenbergia sobolifera. A, Assimilation rate (A); $B$, leaf conductance $\left(g_{\mathrm{c}}\right)$; and $C$, intercellular $\mathrm{CO}_{2}$ concentration $\left(c_{i}\right)$ as functions of light. Plants were grown for 28-35 days at the following light levels (same daily fluence rate): $O$, light fleck $=15 \mu \mathrm{mol} \mathrm{m}^{-2} \mathrm{~s}^{-1}$ for $9 \mathrm{~h}$ plus two 10 -min periods of $500 \mu \mathrm{mol} \mathrm{m} \mathrm{m}^{-2} \mathrm{~s}^{-1}$. low light $=15 \mu \mathrm{mol} \mathrm{m}^{-2} \mathrm{~s}^{-1}$ for 20 h. Data are means and SE of three plants. 


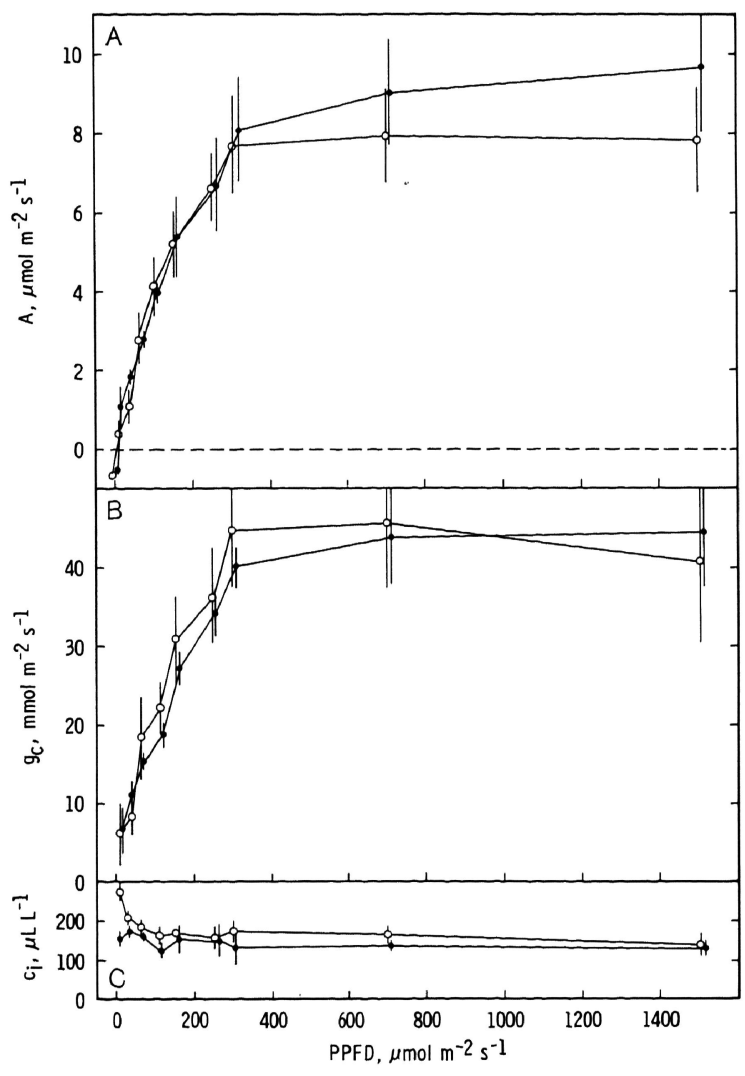

FIG. 3.-Muhlenbergia schreberi. A, Assimilation rate (A); $B$, leaf conductance $\left(g_{\mathrm{c}}\right)$; and $C$, intercellular $\mathrm{CO}_{2}$ concentration $\left(c_{\mathrm{i}}\right)$ as functions of light. Plants were grown for 28-35 days at the following light levels (same daily fluence rate): $\bigcirc$, light fleck $=15 \mu \mathrm{mol} \mathrm{m} \mathrm{m}^{-2} \mathrm{~s}^{-1}$ for $9 \mathrm{~h}$ plus two 10 -min periods of $500 \mu \mathrm{mol} \mathrm{m} \mathrm{m}^{-2} \mathrm{~s}^{-1}$. , low light $=15 \mu \mathrm{mol} \mathrm{m}^{-2} \mathrm{~s}^{-1}$ for 20 h. Data are means and SE of three plants.

obtained for the same species grown in the laboratory at $15-25 \mu \mathrm{mol} \mathrm{m}^{-2} \mathrm{~s}^{-1}$ under a 12 -h photoperiod (SMITH and MARTIN 1987b). Photosynthetic saturation below $400 \mu \mathrm{mol} \mathrm{m}^{-2} \mathrm{~s}^{-1}$ indicates that the plants are unable to utilize high PPFD fully. Equal photosynthetic rates of plants receiving short periods of high PPFD and those receiving a constant low level of PPFD indicate that higher PPFD levels, while not being utilized, do not cause any damage to the photosynthetic system. This is further emphasized by the $c_{\mathrm{i}}$ values, which decrease with increasing instantaneous PPFD and were in the range for $\mathrm{C}_{4}$ plants (ca. $100 \mu \mathrm{L} \mathrm{L}^{-1}$ ) (WONG et al. 1985; WARD and WoOLHOUSE 1986).

Results of the light fleck experiment, when combined with those of laboratory plants grown at high, medium, and low PPFD (SMITH and MARTIN $1987 b$ ), emphasize that $M$. frondosa and $M$. sobolifera can adjust to the total quanta available in a variety of light environments and that their chl is not damaged by brief periods of high PPFD. It is unclear whether the greater chl concentration observed in M. schreberi under low PPFD reflects chl damage by short periods of high PPFD or chl synthesis under constant low PPFD.

\section{FIELD PHOTOSYNTHESIS}

The pattern of photosynthetic responses to PPFD (figs. 4, 5) of $M$. frondosa and $M$. sobolifera in the field was similar to that observed in the laboratory (SMITH and MARTIN 1987b): (1) A increased in conjunction with $g_{c}$, resulting in a relatively constant $c_{\mathrm{i}}$; (2) saturation of A with respect to instantaneous PPFD occurred at ca. $200-400 \mu \mathrm{mol} \mathrm{m}^{-2}$ $\mathrm{s}^{-1}$; and (3) maximum rates of A for $M$. frondosa were higher than for $M$. sobolifera. Muhlenbergia sobolifera, however, exhibited substantially higher

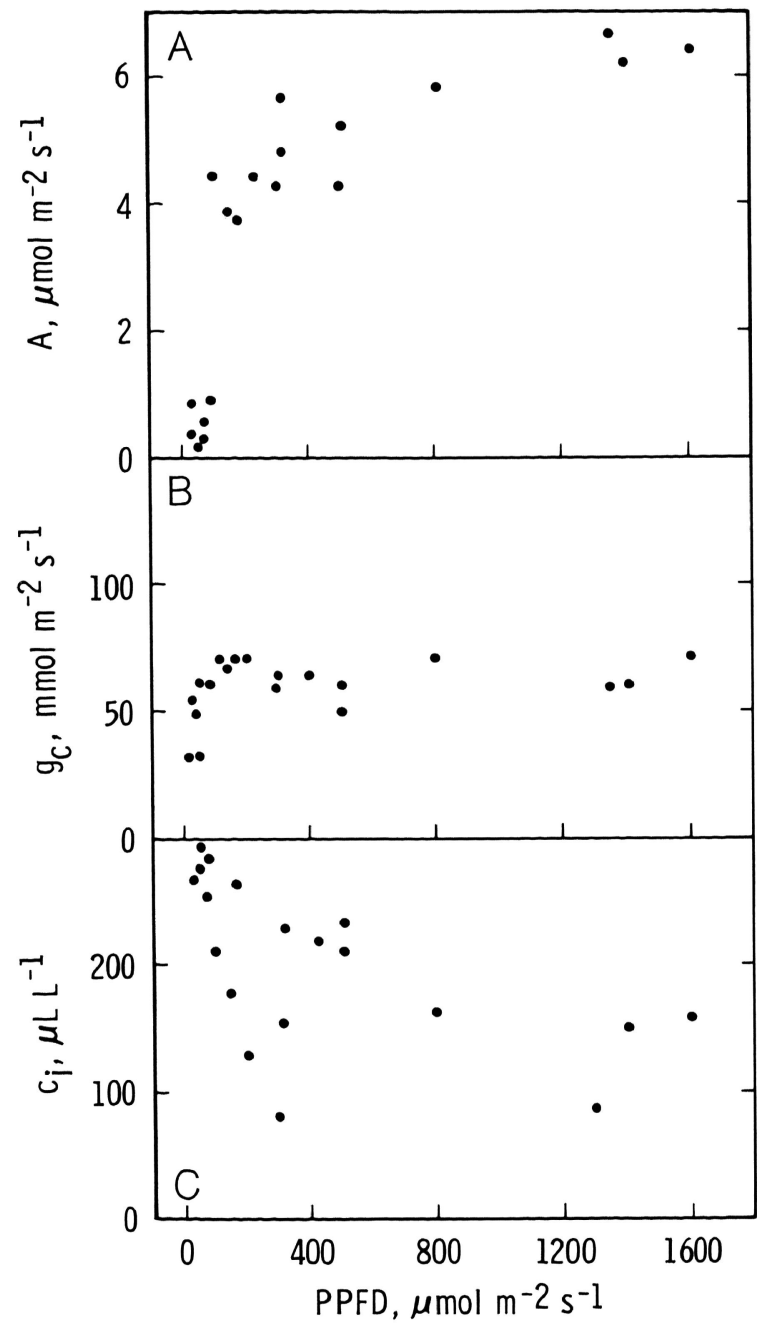

FIg. 4.-Muhlenbergia frondosa. A, Assimilation rate (A); $B$, leaf conductance $\left(g_{c}\right)$; and $C$, intercellular $\mathrm{CO}_{2}$ concentration $\left(c_{\mathrm{i}}\right)$ as functions of light. Each data point represents a measurement in the field on a single attached leaf. 


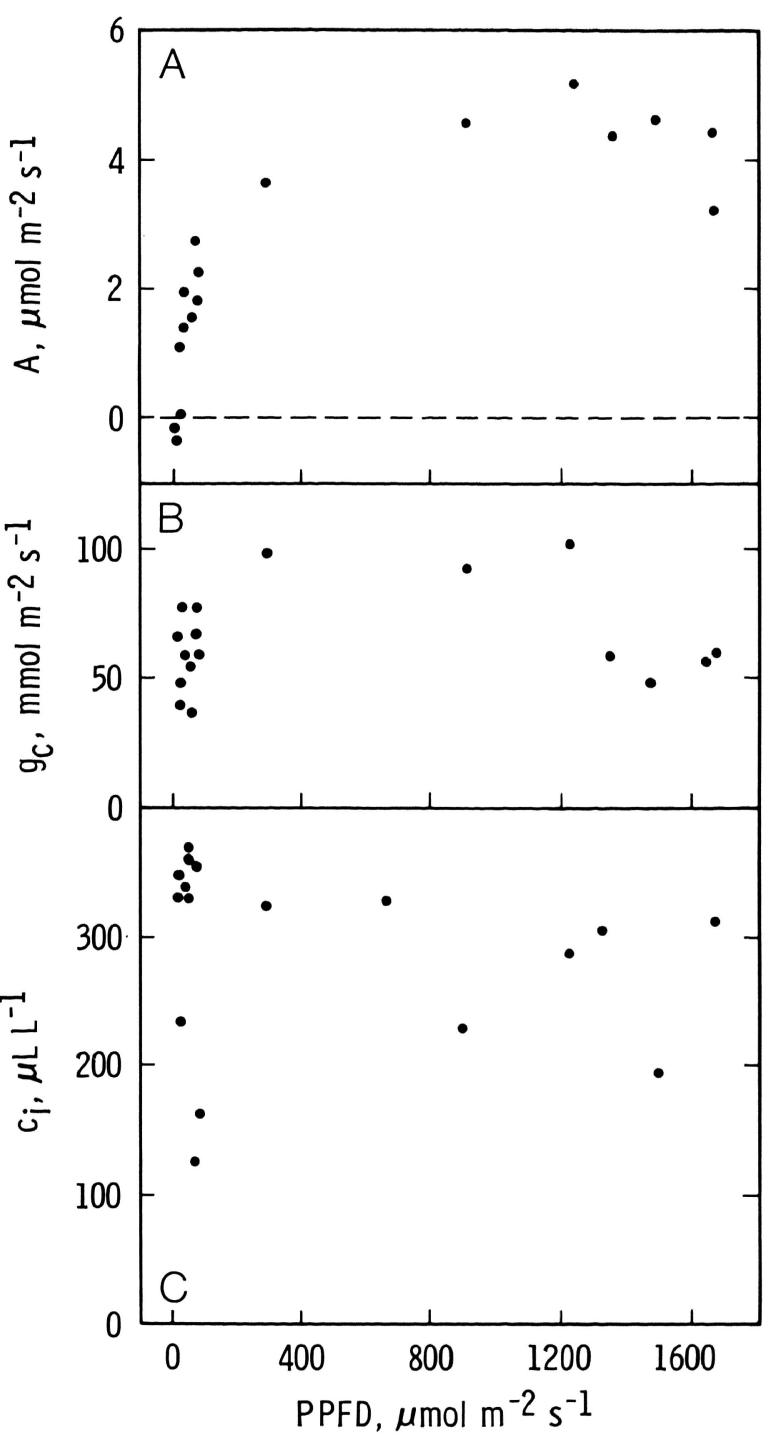

FIG. 5.-Muhlenbergia sobolifera. A, Assimilation rate (A); $B$, leaf conductance $\left(g_{c}\right)$; and $C$, intercellular $\mathrm{CO}_{2}$ concentration $\left(c_{i}\right)$ as functions of light. Each data point represents a measurement in the field on a single attached leaf. $g_{\mathrm{c}}$ in the field than in the laboratory, resulting in higher values for $c_{\mathrm{i}}$ than normal for $\mathrm{C}_{4}$ plants. The high $g_{c}$ observed in situ may reflect the relatively cool temperatures and high soil moisture prevalent at the study site during measurements, in addition to the late time of measurement (late summer). Both $M$. frondosa and $M$. sobolifera have positive carbon exchange at ca. $10 \mu \mathrm{mol} \mathrm{m} \mathrm{m}^{-2} \mathrm{~s}^{-1}$ PPFD, indicating very low rates of respiration. This can be considered an adaptation to growth under shaded conditions and may be crucial to the survival of these species in understory habitats.

Apparently, the $\mathrm{C}_{4}$ syndrome in these species of Muhlenbergia, as well as in Microstegium vimenium (WINTER et al. 1982), Paspalum conjugatum (WARD and WoOlHOUSE 1986), and several species of Euphorbia (PEARCY et al. 1982; PEARCY and CALKIN 1983), does not impose an inherent limitation on the ability to adjust to shaded habitats. From this transplant study, which corroborates our laboratory study (SMITH and MARTIN 1987a), it is clear that, although these understory species of Muhlenbergia survive at low levels of PPFD, they produce significantly more biomass when grown at higher levels of PPFD. They are not, therefore, operating at their physiological optimum in the habitats in which they occur. We hypothesize that ecological factors play a crucial role in determining the presence of these grasses and perhaps other shade-tolerant $\mathrm{C}_{4}$ species in forest understories.

\section{Acknowledgments}

We thank the Experimental \& Applied Ecology Program for the use of facilities and permission to collect plants. This investigation was supported by University of Kansas General Research Allocation 3397-XO-0038 and Biomedical Sciences Support grant RR07037.

\section{LITERATURE CITED}

BJÖRKMAN, O. 1981. Responses to different quantum flux densities. Pages 57-107 in A. Pirson and M. H. ZimmermanN, eds. Encyclopedia of plant physiology. Vol. 12A. SpringerVerlag, New York.

BJÖRKMAN, O., and J. BERRY. 1973. High efficiency photosynthesis. Sci. Am. 229:80-93.

BJörkman, O., N. K. Boardman, J. M. Anderson, S. W. THORPE, D. J. GOODCHILD, and N. A. PYLEOTIS. 1972. Effects of light intensity during growth of Atriplex patula on the capacity of photosynthetic reactions, chloroplast components and structures. Carnegie Inst. Wash. Yearb. 71:115-135.

BoARdMAN, N. K. 1977. Comparative photosynthesis of sun and shade plants. Annu. Rev. Plant Physiol. 28:355-377.

BROWN, W. V. 1977. The Kranz syndrome and its subtypes in grass systematics. Mem. Torrey Bot. Club 23:1-97.
Chabot, B. F., T. W. JuRIK, and J. F. Chabot. 1979. Influence of instantaneous and integrated light-flux density on leaf anatomy and photosynthesis. Am. J. Bot. 66:940-945.

DOLINER, L. $\dot{H}$., and P. A. JOLLIFFE. 1979. Ecological evidence concerning the adaptive significance of the $\mathrm{C}_{4}$ dicarboxylic acid pathway of photosynthesis. Oecologia 38:23-24.

FARQuHAR, G. D., and S. vON CAEMMERER. 1982. Modelling of photosynthetic response to environmental conditions. Pages 549-587 in O. L. Lange, P. S. Nobel, C. B. Osmond, and H. ZIEGLER, eds. Encyclopedia of plant physiology. Vol. 12B. Springer-Verlag, New York.

GRANT, J. A., and K. RYUGO. 1984. Influence of within-canopy shading on net photosynthetic rate, stomatal conductance and chlorophyll content of kiwi fruit leaves. Hort. Sci. 19:834-836. 
Great Plains Flora Association. 1986. Flora of the Great Plains. University of Kansas Press, Lawrence. 1,392 pp.

HATCH, M. D., and C. B. Osmond. 1976. Compartmentation and transport in $\mathrm{C}_{4}$ photosynthesis. Pages 144-184 in W. RUHLAND, ed. Encyclopedia of plant physiology. Vol. 3A. Springer-Verlag, New York.

HuRD, R. G., and J. H. M. ThORNLey. 1974. An analysis of the growth of young tomato plants in water culture at different light integrals and $\mathrm{CO}_{2}$ concentrations. Ann. Bot. 38:375-388.

Kortschak, H. P., C. E. HartT, and G. D. BuRr. 1965. Carbon dioxide fixation in surgarcane leaves. Plant Physiol. 40:209-213.

Masarovičová, E., and P. Minarčic. 1985. Photosynthetic response and adaptation of Fagus sylvatica L. trees to light conditions. II. Leaf chlorophyll contents, leaf dry matter, specific leaf area and mass, stomatal density. Biologia (Bratislavia) 40:473-481.

NoBel, P. S. 1976. Photosynthetic rates of sun versus shade leaves of Hyptis emoryi Torr. Plant Physiol. 58:218-223.

PEARCY, R. W. 1983. The light environment and growth of $\mathrm{C}_{3}$ and $\mathrm{C}_{4}$ tree species in the understory of a Hawaiian forest. Oecologia 58:19-25.

PeARCY, R. W., and H. W. CALKIN. 1983. Carbon dioxide exchange of $\mathrm{C}_{3}$ and $\mathrm{C}_{4}$ tree species in the understory of a Hawaiian forest. Oecologia 58:26-32.

PEARCY, R. W., and J. R. EHLERINGER. 1984. Comparative ecophysiology of $\mathrm{C}_{3}$ and $\mathrm{C}_{4}$ plants. Plant Cell Environ. 7:1-13.

Pearcy, R. W., K. Osteryoung, and H. W. Calkin. 1985. Photosynthetic responses to dynamic light environments by Hawaiian trees: time course of $\mathrm{CO}_{2}$ uptake and carbon gain during sunflecks. Plant Physiol. 79:896-902.

Pearcy, R. W., K. Osteryoung, and D. Randall. 1982. Carbon dioxide exchange characteristics of $\mathrm{C}_{4}$ Hawaiian $\mathrm{Eu}$ phorbia species native to diverse habitats. Oecologia 55:333341.

SĚstÁK, Z., J. ČATSKÝ, and P. G. JARVIS. 1971. Plant photo- synthetic production: manual of methods. Junk, The Hague. $818 \mathrm{pp}$.

SMITH, M., and C. E. MARTIN. 1987a. Growth and morphological responses to irradiance in three forest understory species of the $\mathrm{C}_{4}$ grass genus Muhlenbergia. Bot. GAz. 148:141148.

- 1987b. Photosynthetic responses to irradiance in three forest understory species of the $\mathrm{C}_{4}$ grass genus Muhlenbergia. BOT. GAz. 148:275-282.

SOKAL, R. R., and F. J. RoHLF. 1981. Biometry. 2d ed. W. H. Freeman, San Francisco. 859 pp.

TeERI, J. A., and L. G. STOWE. 1976. Climatic patterns and the distribution of $\mathrm{C}_{4}$ grasses in North America. Oecologia 23:1-12.

Teeri, J. A., L. G. Stowe, and D. A. Livingstone. 1980. The distribution of $\mathrm{C}_{4}$ species of the Cyperaceae in North America in relation to climate. Oecologia 47:307-310.

Tieszen, L. L., M. M. Seniyamba, S. K. Imbamba, and J. H. Troughton. 1979. The distribution of $C_{3}$ and $C_{4}$ grasses and carbon isotope discrimination along an altitudinal gradient in Kenya. Oecologia 37:337-350.

WARD, D. A., and H. W. WoOlHouse. 1986. Comparative effects of light during growth on the photosynthetic properties of NADP-ME type $\mathrm{C}_{4}$ grasses from open and shaded habitats: gas exchange, leaf anatomy and ultrastructure. Plant Cell Environ. 9:261-270.

Wells, P. V., and G. E. Morley. 1964. Composition of Baldwin Woods: an oak-hickory forest in eastern Kansas. Trans. Kansas Acad. Sci. 67:65-69.

WINTER, K., M. R. SCHMITT, and G. E. EdWARdS. 1982. Microstegium vimineum, a shade adapted $\mathrm{C}_{4}$ grass. Plant Sci. Lett. 24:311-318.

Wong, S. C., I. R. Cowan, and G. D. Farquhar. 1985. Leaf conductance in relation to rate of $\mathrm{CO}_{2}$ assimilation. I. Influence of nitrogen nutrition, phosphorus nutrition, photon flux density and ambient partial pressure of $\mathrm{CO}_{2}$ during ontogeny. Plant Physiol. 78:821-825. 